\title{
Cancer-initiating cells derived from human rectal adenocarcinoma tissues carry mesenchymal phenotypes and resist drug therapies
}

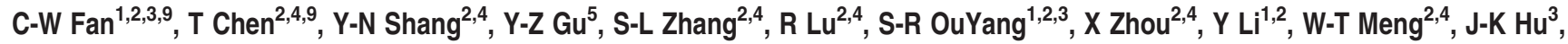 \\ $\mathrm{Y} \mathrm{Lu}^{6}, \mathrm{X}-\mathrm{F} \mathrm{Sun}{ }^{7}, \mathrm{H} \mathrm{Bu}^{8}, \mathrm{Z}-\mathrm{G} \mathrm{Zhou}^{*, 1,2,3}$ and X-M Mo ${ }^{\star, 2,4}$
}

Accumulating evidence indicates that cancer-initiating cells (CICs) are responsible for cancer initiation, relapse, and metastasis. Colorectal carcinoma (CRC) is typically classified into proximal colon, distal colon, and rectal cancer. The gradual changes in CRC molecular features within the bowel may have considerable implications in colon and rectal CICs. Unfortunately, limited information is available on CICs derived from rectal cancer, although colon CICs have been described. Here we identified rectal CICs (R-CICs) that possess differentiation potential in tumors derived from patients with rectal adenocarcinoma. The R-CICs carried both CD44 and CD54 surface markers, while R-CICs and their immediate progenies carried potential epithelialmesenchymal transition characteristics. These R-CICs generated tumors similar to their tumor of origin when injected into immunodeficient mice, differentiated into rectal epithelial cells in vitro, and were capable of self-renewal both in vitro and in vivo. More importantly, subpopulations of R-CICs resisted both 5-fluorouracil/calcium folinate/oxaliplatin (FolFox) and cetuximab treatment, which are the most common therapeutic regimens used for patients with advanced or metastatic rectal cancer. Thus, the identification, expansion, and properties of R-CICs provide an ideal cellular model to further investigate tumor progression and determine therapeutic resistance in these patients.

Cell Death and Disease (2013) 4, e828; doi:10.1038/cddis.2013.337; published online 3 October 2013

Subject Category: Cancer

Colorectal cancer (CRC) is one of the most common malignant tumors in both Western and Eastern countries ${ }^{1}$ and is typically classified as proximal colon, distal colon, and rectal cancer. The incidence as well as tumor genetic and epigenetic features of CRC differ by tumor location. ${ }^{2}$ In Chinese populations, rectal cancer is the most common malignant tumor of the lower digestive tract and represents $>60 \%$ of tumors at all subsites of CRCs. ${ }^{3}$ With improving surgical techniques and drug therapy, the 5-year survival rate of patients with rectal cancers has increased during the past decade. ${ }^{4}$ However, tumor recurrence and metastasis, which develop after resection, are virtually inevitable and are a major cause of death in rectal cancer patients.

Increasing evidence suggests that therapeutic resistance is mediated by cancer-initiating cells (CICs), which are a small subset of cancer cells that may be responsible for cancer initiation, development, and relapse. ${ }^{5-7}$ Putative $\mathrm{CIC}$ populations have been identified in several types of solid tumors, such as brain, ${ }^{8}$ breast cancer, ${ }^{9}$ melanoma, ${ }^{10}$ pancreatic adenocarcinoma, ${ }^{11}$ lung cancer, ${ }^{12}$ gastric adenocarcinoma, ${ }^{13}$ and colon cancer. $6,14,15$ Recently used and prominent techniques based on the expression of specific markers and functional stem cell-like properties, including high clonogenicity, differentiation capacity, spheroid formation, and the ability to reproduce xenograft tumors in immunodeficient mice, are becoming standard assays for CIC identification.

Over the past few years, several surface markers have been identified on colon CICs, such as CD133, ${ }^{14,15}$ CD44, ${ }^{16,17} \mathrm{CD} 166,{ }^{18}$ and ALDH1. ${ }^{19,20}$ Although initial studies identified CD133 as a reliable CIC marker in primary human CRCs, ${ }^{6,14}$ subsequent studies have shown that CD133 expression is not only restricted to rare $\mathrm{CIC}$ subsets but is also detectable in the majority of metastatic tumor cells and normal intestinal mucosa. ${ }^{21}$ Alternatively, the co-expression

\footnotetext{
${ }^{1}$ Institute of Digestive Surgery, West China Hospital, Sichuan University, Chengdu, People's Republic of China; ${ }^{2}$ Medical Center of Stem Cell Biology, West China Hospital, Sichuan University, Chengdu, People's Republic of China; ${ }^{3}$ Department of Gastrointestinal Surgery, West China Hospital, Sichuan University, Chengdu, People's Republic of China; ${ }^{4}$ Laboratory of Stem Cell Biology, West China Hospital, Sichuan University, Chengdu, People's Republic of China; ${ }^{5}$ Laboratory of Biotherapy of Cancer, State Key Laboratory of Biotherapy, West China Hospital, Sichuan University, Chengdu, People's Republic of China; ${ }^{6}$ Department of Thoracic Oncology, Cancer Center, West China Hospital, Sichuan University, Chengdu, People's Republic of China; ${ }^{7}$ Division of Oncology, Department of Clinical and Experimental Medicine, Faculty of Health Sciences, Country Council of Östegötland, Linköping University, Linköping, Sweden and ${ }^{8}$ Key Laboratory of Transplant Engineering and Immunology, Ministry of Health, West China Hospital, Sichuan University, Chengdu, People's Republic of China

*Corresponding author: Z-G Zhou, Institute of Digestive Surgery, West China Hospital, Sichuan University, No.37, Guoxue Lane, Chengdu 610041, People's Republic of China. Tel: +86 28 85164035; Fax: +86 28 85164035; E-mail: zhou767@163.com

or X-M Mo, Laboratory of Stem Cell Biology, West China Hospital, Sichuan University, No.37, Guoxue Lane, Chengdu 610041, People's Republic of China. Tel: +86 28 85164017; Fax: +86 28 85164047; E-mail: xmingmo@yahoo.com

${ }^{9}$ These authors contributed equally to this work.

Keywords: rectal adenocarcinoma; cancer-initiating cells (CICs); chemoresistance; CD44; CD54

Abbreviations: CIC, cancer-initiating cell; CRC, colorectal cancer; SFM, serum-free medium; SCM, serum-containing medium; FACS, fluorescence-activated cell sorting

Received 07.12.12; revised 21.7.13; accepted 12.8.13; Edited by Y Shi
} 
of CD44, CD166, and EpCAM in tumor cells has been reported to more specifically identify the CIC pool than CD133 expression alone. ${ }^{22}$ The role of colon CICs in the establishment and maintenance of metastatic disease has been evaluated in several recent studies. ${ }^{7}$ The $\mathrm{CIC}$ theory of tumorigenesis and metastasis states that a primary mechanism of treatment resistance in metastatic disease is the resistance of $\mathrm{CICs}$ to traditional chemotherapy. Chemotherapy resistance of CICs has been described in a variety of epithelial malignancies, including colon cancer. ${ }^{20}$

Taken together, the studies to date indicate that although enrichment and isolation of CICs was shown to be an effective tool to further investigate biological behavior of malignant tumors, the isolation and culture of CICs derived from rectal cancer are rarely reported. O'Brien et al. ${ }^{14}$ previously mentioned that one subsite of colon cancer may not be representative of all forms of colon cancers. Furthermore, genetic and epigenetic features of the rectum are distinct from the colon. Therefore, in this study we isolated and identified rectal CICs (R-CICs) for further investigation of the biological properties of $\mathrm{CICs}$ in rectal cancer.

\section{Results}

The malignancy in rectospheres expanded by culture under serum-free conditions. A self-renewal capability is a major property of stem cells, and spheroid formation is a selfrenewal index. Culture under serum-free conditions has been used to expand stem-like spheroid cells from several primary solid tumors. Primary cells derived from serum-free culture more accurately mirror the original genotype and tumor morphology of the cells derived directly from endogenous human tumor tissues. $6,9,15$ Thus we first enriched the CICs as rectospheres from human primary rectal adenocarcinoma cells that were isolated from samples surgically removed from 30 human patients who had not received neoadjuvant chemoradiotherapy (Supplementary Table S1). Rectal cancer cells were cultured in a serum-free medium (SFM) supplemented with epidermal growth factor (EGF) and basic fibroblast growth factor (bFGF). After 3-4 weeks, a small fraction of tumor cells formed spheres (first rectospheres; Figure 1a). The SFM was replaced with $20 \%$ fetal bovine serum-containing medium (SCM) for the differentiation of spheres. ${ }^{15}$ The spherical cells gradually aggregated into clusters of polygonal cells and exhibited the typical epitheliallike cell morphology in culture together with expression of cytokeratin 20 (CK20) when restricted to differentiated cells in intestinal epithelium (Figures $1 \mathrm{a}$ and $\mathrm{b}$ ). The expression of CDX2, cytokeratin 7 (CK7), and CK20 was detected in both serum cultured and rectosphere cells. The majority of cells within the rectospheres were positive for CDX2 and negative for CK7 and CK20. The serum-induced differentiated cells expressed CDX2 and CK20, but not CK7 (Figure 1c), which is a typical pattern of rectal cancer cells. ${ }^{6,14}$ Moreover, the intestinal stem cell markers, Bmi1 and Lgr5, were positively expressed in the majority of spherical cells but not in serumcultured cells (Figure 1d). Incubation of cells in SFM is therefore a useful approach for expanding malignant rectospheres.
To compare the relative malignancy between the expanded rectospheres and differentiated rectal cancer cells, both cell types were injected into immunodeficient mice, and growth was assessed. We found that the rectospheres formed tumor masses 2 weeks post injection, whereas $1 \times 10^{6}$ differentiated primary rectal cancer cells did not give rise to any detectable tumors at 8 weeks post injection (Figures 1e and f). These results indicate that cells derived from rectospheres possess differentiation potential and stronger tumorigenicity than differentiated cells in mice.

$\mathrm{CD}_{4}{ }^{+} \mathrm{CD}^{+}{ }^{+}$cells derived from rectospheres exhibit self-renewal capability. It is well established that not all cells derived from tumorigenic spheres can initiate tumors in mice. $^{6,23}$ The isolation and identification of CICs are based on the expression of specific markers, such as CD44, CD24, CD29, CD133, CD326, and CXCR4, which have all been proposed as effective markers in several types of CICs. In this context, the existence of various potential $\mathrm{CIC}$ populations in isolated rectospheres and differentiated cells was evaluated. We found that there were no differences in marker expression in spherical and differentiated cells, with the exception of two adhesion molecules, CD44 and CD54 (Figure $2 \mathrm{a}$ and Supplementary Figure S1a). Both proteins were positively expressed in tumor spherical cells (Figures $2 \mathrm{a}$ and $\mathrm{b}$ and Supplementary Figure S1b) and gradually decreased after tumor spheres were cultured in SCM (Supplementary Figures S1b and c).

Malignant cells harbor more stemness traits, ${ }^{24}$ and therefore we examined stemness and differentiation markers in rectospheres. We sorted spheroid cells based on expression of CD44/CD54 and then examined stem cell markers among the different cellular subpopulations $\left(\mathrm{CD} 44^{+} \mathrm{CD}_{4}{ }^{+}, \mathrm{CD}_{4}{ }^{+} \mathrm{CD}_{4}{ }^{-}, \mathrm{CD}_{4}{ }^{-} \mathrm{CD} 54^{+}, \mathrm{CD}^{+} 4^{-}\right.$ $\mathrm{CD}_{54}{ }^{-}$) derived from rectospheres. Compared with the expression levels of relative intestinal stemness genes, the levels were significantly higher in $\mathrm{CD} 44^{+} \mathrm{CD} 54^{+}$cells, whereas CK20 levels were lower (Figure 2c). We next investigated the self-renewal capacity of cellular subpopulations based on CD44 and CD54 expression. Double-positive cells had significantly greater self-renewal ability compared with the other subpopulations (Figure 2d). We then seeded one cell from each subpopulation in individual wells of a 96-well plate and assessed sphere formation after 14 days. ${ }^{13}$ CD $44^{+}{ }^{+} D 54^{+}$cells were more capable of forming spheres than populations with other surface marker combinations. We were also able to passage the sphere generated from a single CD $44^{+} \mathrm{CD} 54^{+}$cell several times in vitro (Figures $2 d$ and $e$ ), suggesting that rectospheres originated from a CD44 ${ }^{+} \mathrm{CD}_{4} 4^{+}$single cell, rather than having developed by mere cell aggregation. Importantly, the other cellular subpopulations were unable to produce any subculturable rectospheres. These results indicate that CD $44{ }^{+}{ }^{+} D 54{ }^{+}$cells possess sustained sphere formation and self-renewal abilities in culture.

$\mathrm{CD}_{4}{ }^{+} \mathrm{CD}^{-} 4^{+}$cells exhibit potential epithelialmesenchymal transition (EMT) characteristics. We next analyzed the relative EMT gene expression of the different cellular subpopulations or rectospheres. E-cadherin and 

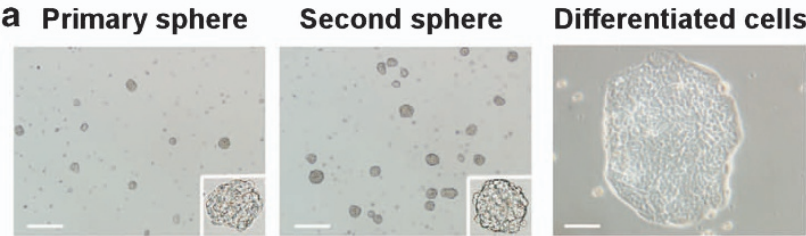

C Tumorigenic Spheres
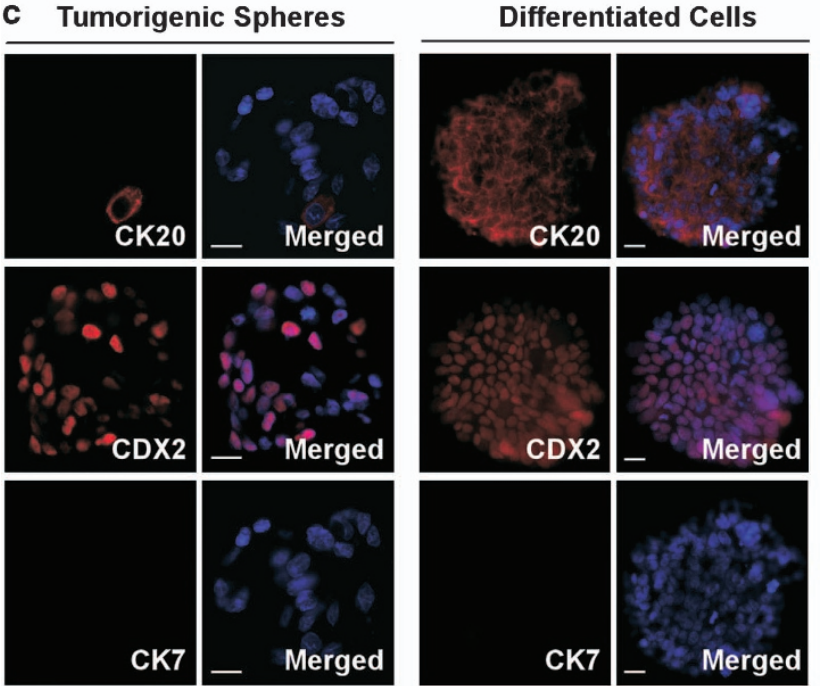

d
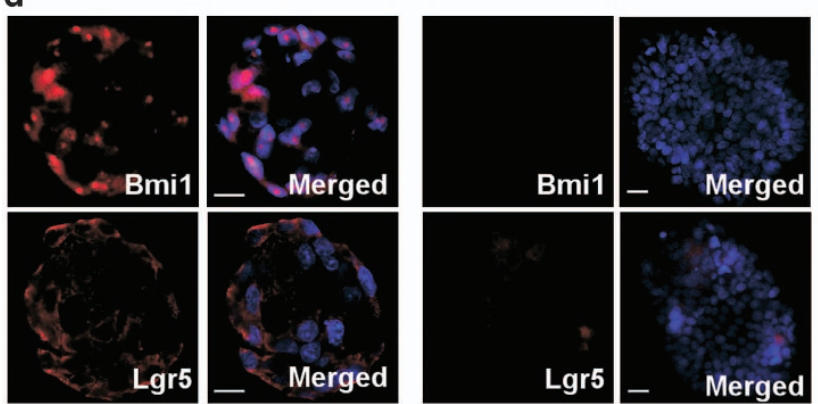

b
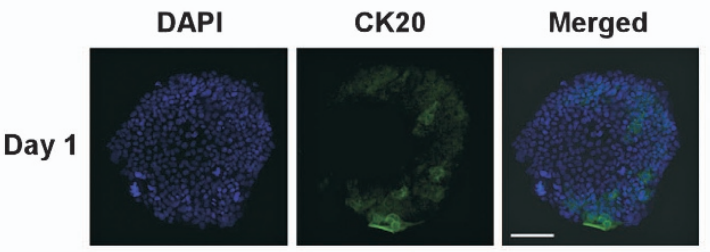

Day 3
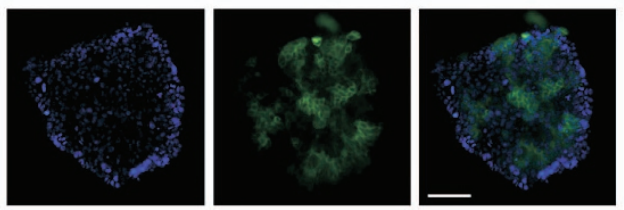

Day 7
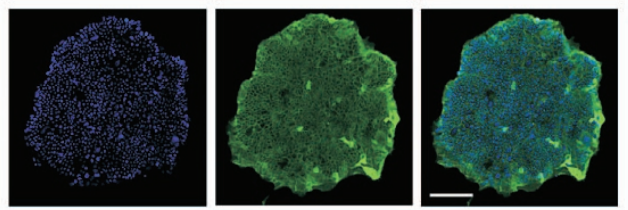

e
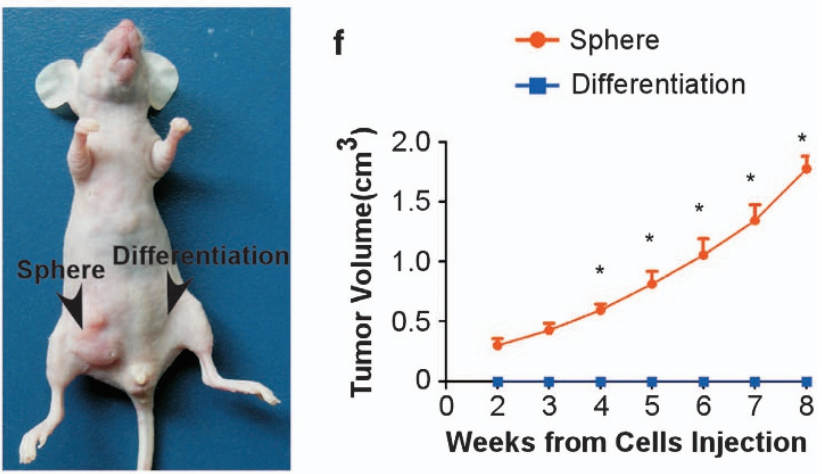

Figure 1 The differentiation potential and tumorigenic capacity of rectospheres in vitro. (a) Example of tumor spheres generated from a human rectal cancer sample that were passaged twice and differentiated cell. Primary spheres: spheres directly generated from human tumor tissues. Secondary spheres: spheres representing the second passage of primary spheres. Bars $=500 \mu \mathrm{M}$. Differentiated cells: spheroids were induced by $20 \%$ fetal bovine serum. One representative of four independent spheroid cultures is shown. Bars $=50 \mu \mathrm{M}$. (b) Spheres were cultured in SCM and analyzed by immunofluorescence to detect the differentiation marker CK20 at different time points. Bars $=50 \mu \mathrm{M}$. (c) Immunofluorescent analysis using CK20 (red), CDX2 (red), CK7 (red), and DAPI (4,6-diamidino-2-phenylindole; blue) stains. One representative image of three different tumors is shown. (d) Bmi1 and Lgr5 expressed on cells from rectospheres (left panels) and rectosphere-derived differentiation progeny (right panels). Nuclei were counterstained by DAPI (blue). One representative experiment of three different tumors is shown. Bars $=25 \mu \mathrm{M}$. (e) The example shows that spheres cultured in SFM, but not in SCM, recapitulate tumors in nude mice. (f) Tumorigenic potential of tumor spheres after subcutaneous injection. Size of subcutaneous rectal carcinoma tumors generated from $10^{3}$ sphere cells and $1 \times 10^{6}$ differentiated cells. Data are mean \pm S.D. of two independent experiments, each performed with cells from different donors $\left({ }^{\star} P<0.01\right.$; patients 9 and 15$)$

EpCAM, which are both epithelial markers of colorectal mucosa, were highly expressed in the spheroids (Figure 3a). In addition, we detected the expression of vimentin, fibronectin, and $\alpha$-SMA proteins, which are typical mesenchymal cell markers (Figure 3a). ${ }^{25}$ Moreover, specific EMT-inducing transcription factors and marker proteins, including fibronectin, vimentin, $\alpha$-SMA, Snail, and Slug were also upregulated based on qRT-PCR and western blot (Figures $3 b$ and c). ${ }^{25,26}$ To test whether CD44 ${ }^{+} \mathrm{CD} 54^{+}$cells possess EMT potential, a transwell migration assay was performed. The migration assay showed that CD $44^{+} \mathrm{CD} 54^{+}$ cells had a higher migratory capacity compared with other subpopulations in different patient tumors (Figure 3d). Collectively, these results indicate that $\mathrm{CD} 44^{+} \mathrm{CD} 54^{+}$cells carry epithelial and mesenchymal phenotypes with distinct expression patterns and potential EMT characteristics.

$\mathrm{CD}_{44}{ }^{+} \mathrm{CD} 54^{+}$rectal cancer cells possess strong tumorigenic capability in vivo. As $\mathrm{CD} 44^{+} \mathrm{CD} 54^{+}$cells carry self-renewal ability in vitro, we examined whether double-positive cells possessed self-renewal ability in vivo through serial transplantations. ${ }^{7}$ First, the engraftment rate of different cellular subpopulations and different number of cells $(100,500,1000$, and 10000 cells per mouse) was tested. 
a

\begin{tabular}{|c|c|c|c|c|c|c|}
\hline \multicolumn{7}{|c|}{ Expression of potential cancer-initiating cells markers in cells derived from rectospheres and differentiated cells } \\
\hline \multirow[b]{2}{*}{ markers } & \multicolumn{2}{|c|}{ Patient 9} & \multicolumn{2}{|c|}{ Patient 11} & \multicolumn{2}{|c|}{ Patient 15} \\
\hline & rectospheres(\%) & differentiation(\%) & rectospheres(\%) & differentiation(\%) & rectospheres(\%) & differentiation(\%) \\
\hline CD10 & $95.83 \pm 0.55$ & $93.97 \pm 2.08$ & $84.47 \pm 4.01$ & $89.00 \pm 3.24$ & $90.80 \pm 1.50$ & $92.30 \pm 2.44$ \\
\hline CD13 & $5.53 \pm 4.80$ & $1.63 \pm 1.028$ & $2.00 \pm 0.53$ & $0.92 \pm 0.12$ & $3.25 \pm 0.29$ & $1.57 \pm 0.67$ \\
\hline CD20 & $60.53 \pm 2.37$ & $61.93 \pm 2.538$ & $62.13 \pm 1.37$ & $49.00 \pm 1.14$ & $65.53 \pm 0.78$ & $61.40 \pm 1.87$ \\
\hline CD24 & $89.77 \pm 5.25$ & $89.87 \pm 1.208$ & $94.45 \pm 0.64$ & $84.23 \pm 2.27$ & $97.10 \pm 0.61$ & $88.70 \pm 1.28$ \\
\hline CD29 & $98.50 \pm 0.95$ & $99.37 \pm 0.31$ & $98.43 \pm 1.04$ & $99.77 \pm 0.23$ & $98.80 \pm 1.08$ & $99.07 \pm 1.27$ \\
\hline CD44 & $97.77 \pm 0.67$ & $20.60 \pm 3.16$ & $90.83 \pm 3.13$ & $30.97 \pm 0.87$ & $93.63 \pm 2.15$ & $33.00 \pm 3.56$ \\
\hline CD54 & $62.83 \pm 5.99$ & $33.70 \pm 9.37$ & $65.10 \pm 9.80$ & $35.67 \pm 5.85$ & $61.80 \pm 8.94$ & $29.13 \pm 6.51$ \\
\hline CD58 & $95.90 \pm 1.68$ & $95.67 \pm 4.93$ & $97.20 \pm 2.65$ & $99.17 \pm 0.57$ & $97.50 \pm 1.42$ & $95.90 \pm 5.46$ \\
\hline CD66 & $95.23 \pm 2.58$ & $96.20 \pm 2.72$ & $89.50 \pm 3.15$ & $89.43 \pm 0.76$ & $97.10 \pm 1.01$ & $97.27 \pm 2.22$ \\
\hline CD71 & $70.73 \pm 3.17$ & $69.75 \pm 2.61$ & $76.60 \pm 3.74$ & $68.30 \pm 4.09$ & $70.00 \pm 2.96$ & $73.00 \pm 2.72$ \\
\hline CD117 & $2.54 \pm 4.38$ & $0.60 \pm 1.04$ & $4.94 \pm 1.67$ & $5.37 \pm 5.33$ & $0.89 \pm 0.64$ & $1.37 \pm 1.23$ \\
\hline CD133 & $7.63 \pm 0.86$ & $1.54 \pm 0.50$ & $2.99 \pm 0.17$ & $0.53 \pm 0.11$ & $2.97 \pm 0.15$ & $0.95 \pm 0.41$ \\
\hline CD184 & $6.37 \pm 5.93$ & $0.45 \pm 0.32$ & $2.44 \pm 1.20$ & $0.33 \pm 0.16$ & $2.82 \pm 0.99$ & $0.34 \pm 0.06$ \\
\hline CD326 & $79.17 \pm 2.01$ & $89.53 \pm 3.31$ & $75.80 \pm 8.80$ & $71.43 \pm 7.70$ & $90.33 \pm 1.44$ & 86.573 .11 \\
\hline $\mathrm{CD} 44^{+} \mathrm{CD} 54^{+}$ & $44.70 \pm 6.56$ & $18.00 \pm 2.33$ & $57.70 \pm 3.84$ & $21.93 \pm 5.05$ & $59.7 \pm 1.12$ & $20.00 \pm 2.75$ \\
\hline $\mathrm{CD}_{4} 4^{\circ} \mathrm{CD} 133^{+}$ & $2.81 \pm 0.40$ & $0.39 \pm 0.18$ & $0.95 \pm 0.60$ & $0.58 \pm 0.38$ & $1.77 \pm 0.28$ & $1.87 \pm 0.36$ \\
\hline
\end{tabular}

\section{b}

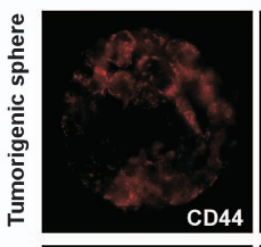

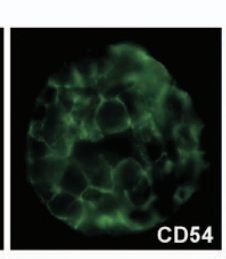
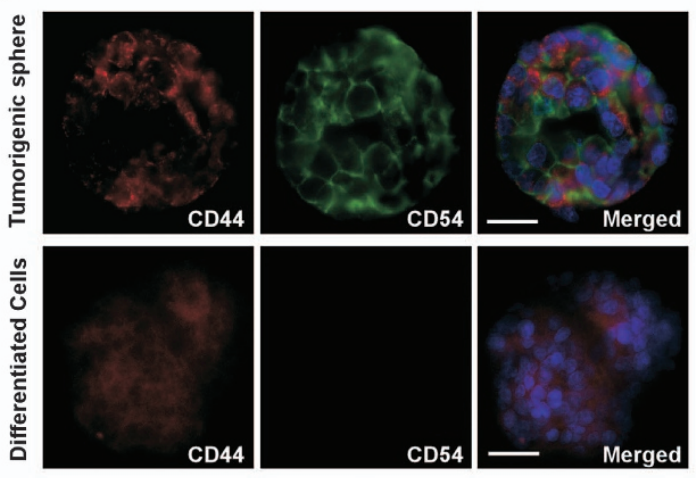

\section{d}

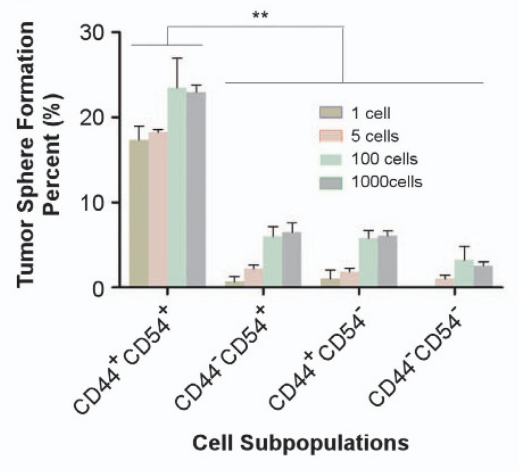

C

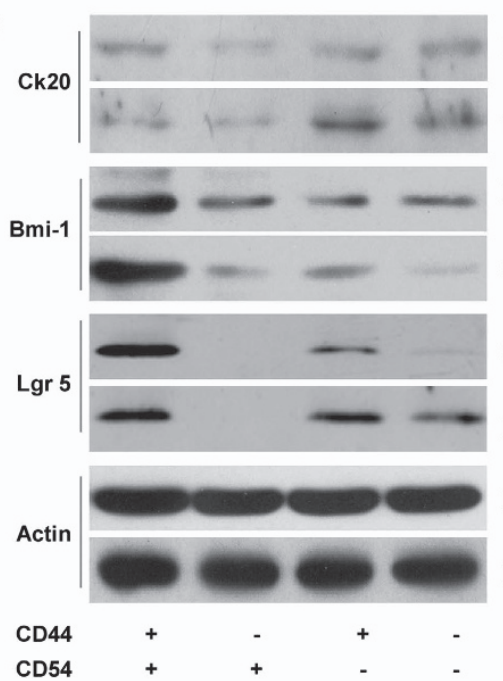

Patient 15

Patient 9

Patient 15

Patient 9

Patient 15

Patient 9

e

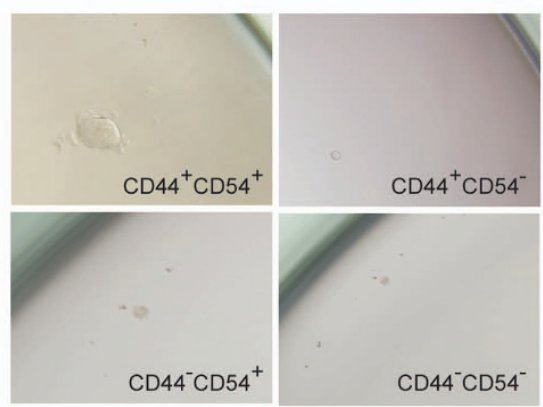

Patient 15
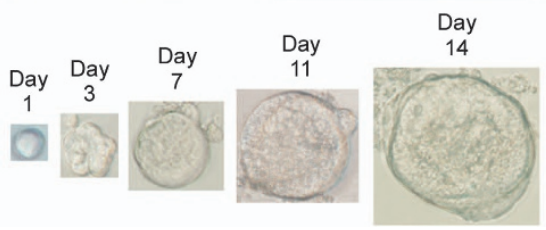

Figure $2 \mathrm{CD}_{4}{ }^{+} \mathrm{CD} 54^{+}$cells derived from rectospheres possess strong self-renewal capability. (a) Flow cytometry analysis of putative $\mathrm{CIC}$ markers on rectospheres and rectosphere-derived differentiation progeny in three independent experiments (patients 9, 11, and 15). (b) Immunofluorescence analysis using antibodies against CD44 (red) and CD54 (green) on cells from rectal cancer spheres (upper panels) and differentiated rectal cancer cells (lower panels). Nuclei were counterstained by DAPI (4,6-diamidino-2phenylindole; blue). One representative image of two different tumors is shown. Bars $=50 \mu \mathrm{m}$. (c) Immunoblotting validation of stemness and differentiation gene expression in different cellular populations derived from two independent donors (patients 9 and 15). (d) Tumor sphere formation ratio derived from different number of CD44 ${ }^{+}$CD54 ${ }^{+}$, $\mathrm{CD} 44^{+} \mathrm{CD} 54^{-}, \mathrm{CD} 44^{-} \mathrm{CD} 54^{+}$, and $\mathrm{CD} 44^{-} \mathrm{CD} 54^{-}$cells in SFM. Data are mean \pm S.D. of three independent experiments, each performed with cells from different donors $\left({ }^{* *} P<0.01\right.$; patients 9,11 and 15$)$. (e) Single $\mathrm{CD} 44^{+} \mathrm{CD} 54^{+}$cell generated one sphere in culture (left upper panel). Phase-contrast microscopy representative images taken at different time points confirmed spheroid growth from single-sorted $\mathrm{CD} 44^{+} \mathrm{CD} 54^{+}$cells. One representative experiment of two different tumors is shown 
a


C
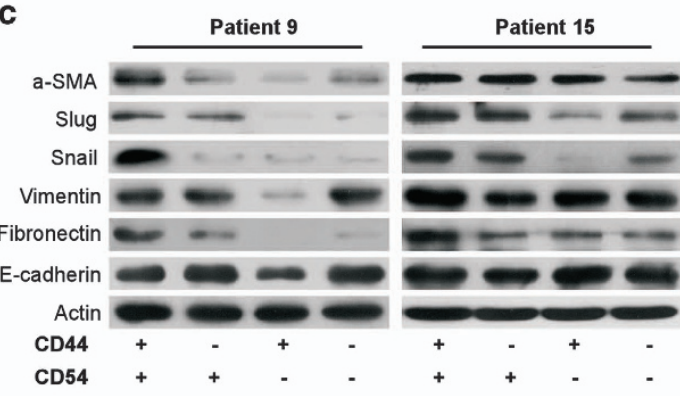
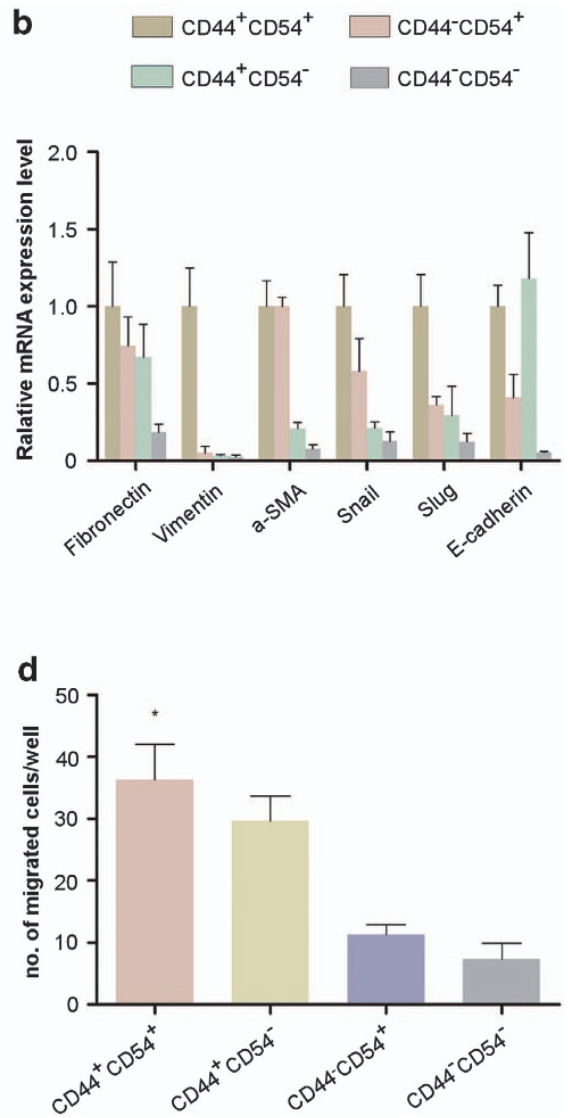

Figure 3 Rectal cancer sphere cells exhibit mesenchymal phenotypes. (a) Confocal images of rectospheres stained with antibodies against E-cadherin (green), EpCAM (green), fibronectin (red), vimentin (red), and $\alpha$-SMA ( $\alpha$-smooth muscle actin; red). One representative image of two different tumors is shown. Bar $=25 \mu \mathrm{M}$. (b) Expression levels of mRNAs encoding E-cadherin, Snail, Slug, fibronectin, vimentin, and $\alpha$-SMA in different cellular subpopulations were determined by real-time reverse transcriptasePCR. Data are mean \pm S.D. of three independent experiments, each performed with cells from different donors (patients 9, 11, and 15). (c) Immunoblotting of EMT-related proteins from lysates of different cell populations isolated from rectospheres of two different patients (patients 9 and 15). (d) Migration capacity of different cellular subpopulations. Data are mean \pm S.D. of three independent experiments, each performed with cells from different donors $\left({ }^{*} P<0.05 ;\right.$ patients 9 , 11, and 15 )

We subcutaneously injected the indicated number of cells into nude mice and found that injection with as few as 100 purified CD44 ${ }^{+}$CD54 ${ }^{+}$cells resulted in tumor formation after 4 weeks (Figures $4 \mathrm{a}$ and b). In contrast, one in five samples of $10000 \mathrm{CD}_{4} 4^{+} \mathrm{CD} 54^{-}$-injected mice formed tumors (Figure 4b). The other cellular subpopulations (CD44$\mathrm{CD}^{+} 4^{+}$and $\left.\mathrm{CD}_{4} 4^{-} \mathrm{CD}_{4}{ }^{-}\right)$did not give rise to any xenotransplant tumors (Table 1). To determine whether the xenotransplant tumors initiated from $\mathrm{CD} 44^{+} \mathrm{CD} 54^{+}$cells were serially transplantable, double-positive cell-generated tumor masses were harvested when the tumor diameters reached $1 \mathrm{~cm}$ and then transplanted again into nude mice (100 cells per mouse). We found that these cells ultimately generated tumors in secondary and tertiary recipients (Table 1). Hematoxylin and eosin staining showed xenograft tumors shared typical rectal cancer morphological features that were observed in the original tumor tissues surgically removed from human patients (Figure 4c). The immunostaining patterns of xenografts were also highly similar to the original human tumors (Figure 4d). ${ }^{14}$

To investigate whether SFM cultures had acquired this novel phenotype not seen in the original tumor, we examined the expression of CD44 and CD54 in human rectal cancer tissue. Both markers were expressed in some of the dissociated cells from human samples (Supplementary Figure S1c). In addition, both $\mathrm{CD} 44^{+} \mathrm{CD} 54^{+}$and CD44 ${ }^{+}$ ${\mathrm{CD} 54^{-}}^{-}$cells exhibited the ability to propagate tumors in xenotransplanted mice; however, double-positive cells produced bulky tumors in recipient mice more efficiently than single-positive cells (Table 1 and Figure 4e). Taken together, these results indicate that $\mathrm{CD} 44^{+} \mathrm{CD} 54{ }^{+}$cells can initiate growth of rectal tumors that inherit the properties of rectal CICs and recapitulate the phenotypes of human primary tumors. Therefore, the self-renewal capability in vivo indicates that CD44 and CD54 are potential biomarkers for identifying $\mathrm{R}-\mathrm{CICs}$.

R-CICs are resistant to apoptosis induced by conventional chemical and targeted drugs. As CICs derived from various solid tumors have been shown to be resistant to chemotherapy, ${ }^{6,7,20}$ we assessed the changes in expression of CD44 and CD54 after culturing rectospherical cells in medium with 5-fluorouracil (5-Fu), oxaliplatin, and cetuximab for 7 days. Cetuximab is a monoclonal antibody that targets 
a
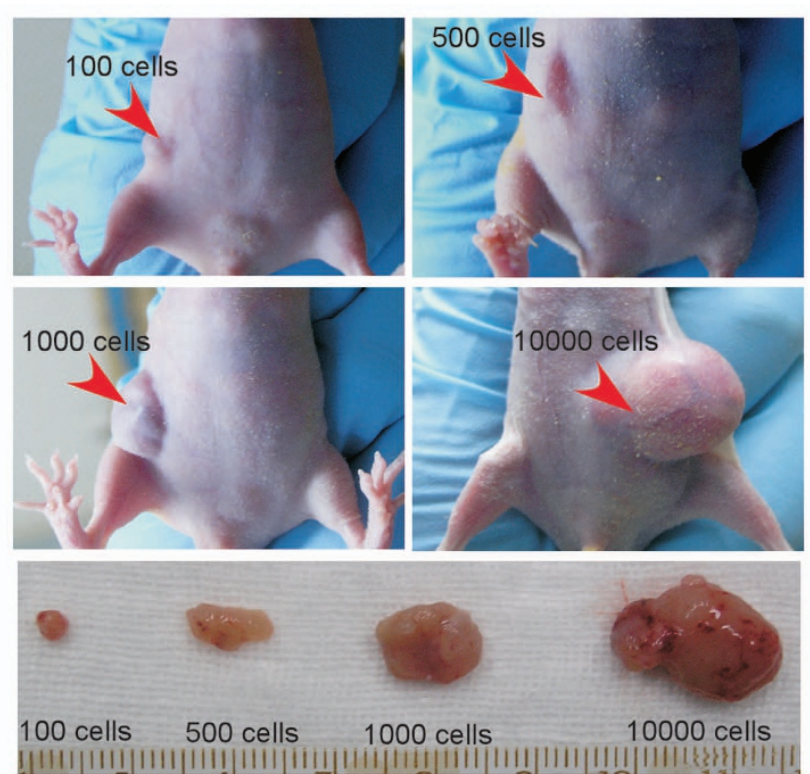

b

$$
\mathrm{CD}_{4} 4^{+} \mathrm{CD} 54^{+}
$$

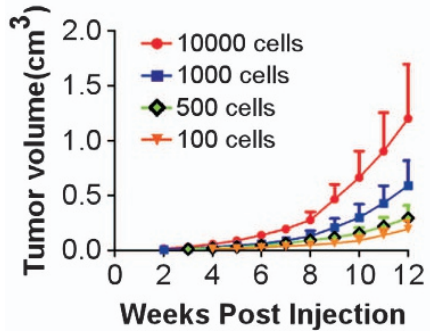

Weeks Post Injection

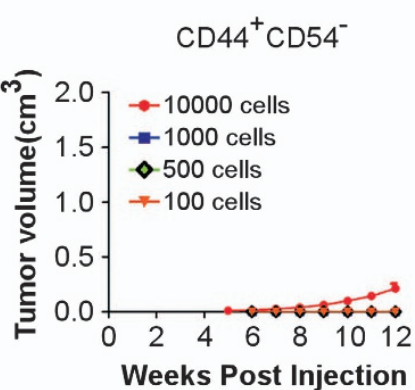

e

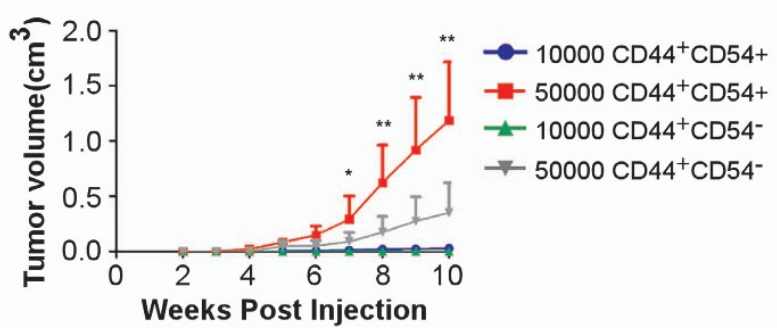

C Human Primary Tumor
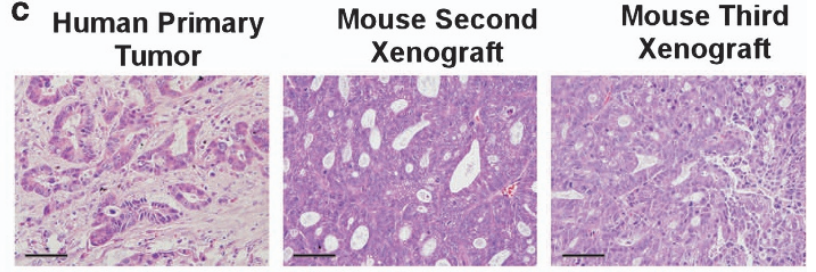

d Human Primary Tumor Mouse Xenograft Tumor
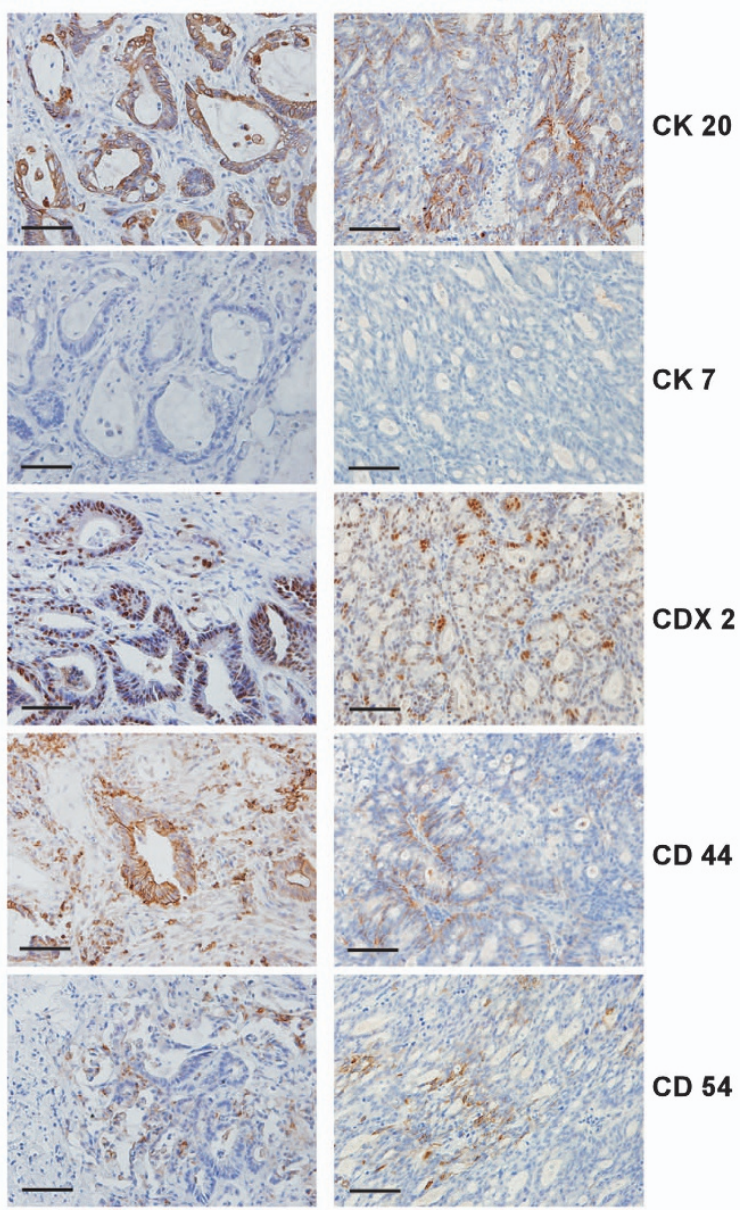

Figure $4 \mathrm{CD} 44^{+} \mathrm{CD} 54^{+}$cells derived from rectospheres have the strongest tumorigenicity among the four cellular subpopulations. (a) Tumor-bearing mice derived from $100,500,1000$, and $10000 \mathrm{CD} 44^{+} \mathrm{CD} 54^{+}$rectal cancer cells and excised subcutaneous tumors. One representative experiment of three different tumors is shown. (b) Size of xenografts of $\mathrm{CD} 44^{+} \mathrm{CD} 54^{+}$and $\mathrm{CD} 44^{+} \mathrm{CD} 54^{-}$derived from rectospheres. Data are mean tumor size \pm S.D. of $3-5$ tumors per group derived from three separate patients (patients 9,11 , and 15). (c) Hematoxylin and eosin analysis of a human rectal cancer section from the original human tumor and corresponding xenografts obtained after injection of sphere cells. Bars $=100 \mu \mathrm{M}$. Second and third xenografts: tumors were obtained from the first and second transplantation, respectively. One representative experiment of two different tumors is shown. (d) Immunohistochemical analysis of relative differentiation and putative R-CIC markers in tissue derived from original human tumor (left panel) and sphere-derived first xenografts (right panel). One representative experiment of two different tumors is shown. Bars $=100 \mu \mathrm{M}$. (e) Size of xenografts of $\mathrm{CD} 44^{+} \mathrm{CD} 54^{+}$and $\mathrm{CD} 44^{+} \mathrm{CD} 54^{-}$sorted from three rectal cancer tissues. Data are mean tumor size \pm S.D. of $3-5$ tumors per group derived from three separate patients $\left({ }^{* *} P<0.01,{ }^{*} P<0.05\right.$; patients 31,32 , and 33 )

epidermal growth factor receptor (EGFR) but exhibits better therapeutic efficacy in $k$-ras wild-type CRC. Therefore, we also examined EGFR expression and the $k$-ras mutation in tumor samples and different cellular subpopulations. The k-ras mutation was not detected in the samples assessed (Figure 5a), but the expression of EGFR was observed (Figure 5b). Following treatment with 5-Fu, oxaliplatin, and cetuximab, the fraction of $\mathrm{CD} 44^{+} \mathrm{CD} 54^{+}$ cells significantly increased (Supplementary Figures S2a and b) while the spheroids clearly decreased in number (Supplementary Figure S2c) compared with controls, indicating that this fraction may be resistant to these agents.

To further validate the resistance of R-CICs to chemotherapy and targeted drugs, we next treated the cellular subpopulations with different concentrations of 5-Fu, oxaliplatin, or cetuximab for 24,48 , or $72 \mathrm{~h}$, respectively. The caco- 2 cell line was used as a positive control owing to its high sensitivity to cetuximab. ${ }^{27}$ We found that CD $44^{+} \mathrm{CD} 54^{+} \mathrm{R}-\mathrm{CIC}$ s had the 
Table 1 Transplantation efficiency of primary rectal cancer-initiating cells

\begin{tabular}{|c|c|c|c|c|c|c|c|}
\hline \multirow[t]{2}{*}{ Cases } & \multirow[t]{2}{*}{ Cell dose } & \multicolumn{4}{|c|}{ Cell subpopulation and (number of primary mice with tumors)/(total number injected) } & \multirow{2}{*}{\multicolumn{2}{|c|}{$\frac{\text { Secondary Tertiary }}{{\text { CD } 44^{+} \text {CD54 }}^{+}}$}} \\
\hline & & $\mathrm{CD}_{4}{ }^{+} \mathrm{CD} 4^{+}$ & $\mathrm{CD}_{4} 4^{+} \mathrm{CD}^{-} 4^{-}$ & $\mathrm{CD}_{4}{ }^{-} \mathrm{CD} 4^{+}$ & $\mathrm{CD}_{4}{ }^{-} \mathrm{CD}_{4} 4^{-}$ & & \\
\hline \multirow[t]{4}{*}{ Patient 9} & 100 & $2 / 3$ & $1 / 5$ & $0 / 5$ & $0 / 5$ & $3 / 3$ & $3 / 3$ \\
\hline & 500 & $3 / 3$ & $0 / 5$ & $0 / 5$ & $0 / 5$ & NA & NA \\
\hline & 1000 & $3 / 3$ & $0 / 5$ & $0 / 5$ & $0 / 5$ & NA & NA \\
\hline & 10000 & $3 / 3$ & $0 / 5$ & $0 / 5$ & $0 / 5$ & NA & NA \\
\hline \multirow[t]{4}{*}{ Patient 15} & 100 & $1 / 3$ & $0 / 5$ & $0 / 5$ & $0 / 5$ & $3 / 3$ & $3 / 3$ \\
\hline & 500 & $3 / 3$ & $0 / 5$ & $0 / 5$ & $0 / 5$ & NA & NA \\
\hline & 1000 & $3 / 3$ & $0 / 5$ & $0 / 5$ & $0 / 5$ & NA & NA \\
\hline & 10000 & $3 / 3$ & $0 / 5$ & $0 / 5$ & $0 / 5$ & NA & NA \\
\hline \multicolumn{8}{|c|}{ Cells from rectal cancer tissue } \\
\hline \multirow[t]{2}{*}{ Patient 31} & 10000 & $2 / 5$ & $0 / 5$ & NA & NA & NA & NA \\
\hline & 50000 & $4 / 5$ & $3 / 5$ & NA & NA & NA & NA \\
\hline \multirow[t]{2}{*}{ Patient 32} & 10000 & $2 / 5$ & $0 / 5$ & NA & NA & NA & NA \\
\hline & 50000 & $5 / 5$ & $2 / 5$ & NA & NA & NA & NA \\
\hline \multirow[t]{2}{*}{ Patient 33} & 10000 & $3 / 5$ & $0 / 5$ & NA & NA & NA & NA \\
\hline & 50000 & $4 / 5$ & $3 / 5$ & NA & NA & NA & NA \\
\hline
\end{tabular}

NA, not assessed

Different numbers of $\mathrm{CD} 44^{+} \mathrm{CD} 54^{+}$and $\mathrm{CD} 44^{+} \mathrm{CD} 54^{-}$cells derived from rectospheres and primary rectal cancer cells from freshly dissociated were implanted into the ventral wall of immunocompromised mice. A hundred CD $44^{+} \mathrm{CD} 54^{+}$cells isolated from the xenografted patient specimen from the first transplantation were then injected into animals and monitored as above for the serial transplantation

highest viability among all the treatment groups (Figure 5c) and displayed resistance to the chemotherapies at all the treatment periods tested $(24,48$, or $72 \mathrm{~h})$. Although the group treated with cetuximab showed the highest number of viable cells, low-dose cetuximab did significantly inhibit the growth of the other groups (Figure 5c). In particular, there were fewer viable cells in the $\mathrm{CD} 44^{+} \mathrm{CD}_{4}{ }^{-}, \mathrm{CD} 44^{-} \mathrm{CD} 54^{+}$, and CD44 ${ }^{-}$CD54 ${ }^{-}$cellular subpopulations at $72 \mathrm{~h}$ post treatment compared with 24 and $48 \mathrm{~h}$ (Figure 5c). Similarly, cellular apoptosis assays showed that $\mathrm{R}$-CICs were resistant to apoptosis induced by the chemotherapeutics and cetuximab (Figure 5d and Supplementary Figure S3).

R-CICs are resistant to the conventional FolFox regimen and cetuximab therapy in vivo. To further investigate the effect of cetuximab, 5-fluorouracil/calcium folinate/oxaliplatin (FolFox), or FolFox-cetuximab on R-CICs, mice were transplanted with tumors derived from R-CICs, CD44 ${ }^{+}$ $\mathrm{CD} 54^{-}$cells, or caco-2 cells and then treated with the indicated agents (Figure 6a). When the xenotransplanted tumors reached $0.2 \mathrm{~cm}^{3}$ in diameter, the chemotherapeutic agents were injected into the mice. The results showed that the tumor growth rate derived from $\mathrm{CD} 44^{+} \mathrm{CD} 54{ }^{+} \mathrm{R}-\mathrm{CICs}$ did not show a statistical difference in the different treatment groups relative to control, while $\mathrm{CD} 44^{+} \mathrm{CD} 54^{-}$and caco- 2 cells generated tumors at a significantly slower rate compared with control in different regimen (Figure 6b). The survival curves of mice derived from treatment and control groups showed that all mice carrying tumors generated from CD $44{ }^{+} \mathrm{CD}^{+}{ }^{+} \mathrm{R}-\mathrm{ClCs}$ were not statistically different from controls and were killed within 120 days in all the regimens (Figure 6c and Supplementary Table S2). Nevertheless, cetuximab, FolFox, and FolFox-cetuximab regimens did significantly increase the overall survival of xenografts derived from CD44 ${ }^{+}$CD54 ${ }^{-}$and Caco-2 cells compared with control mice (Figure $6 \mathrm{c}$ and Supplementary Table S2). Interestingly, either in group $\mathrm{CD} 44^{+} \mathrm{CD} 54^{+}$or $\mathrm{CD} 44^{+}$
$\mathrm{CD}^{-} 4^{-}$, the shortest overall survival occurred in the group treated with FolFox-cetuximab compared with FolFox or cetuximab regimens alone (Supplementary Table S2).

We also frequently observed liver necrosis in mice derived from $\mathrm{CD} 44^{+} \mathrm{CD} 54^{+} \mathrm{R}-\mathrm{ClCs}$, but rarely in mice injected with CD44 ${ }^{+} \mathrm{CD}_{4} 4^{-}$and caco-2 cells (Supplementary Figure S4a). Moreover, R-CIC and $\mathrm{CD} 44^{+} \mathrm{CD} 54^{-}$-injected mice treated with the chemotherapeutic treatments showed sustained weight loss, but mice injected with caco- 2 cells did not (Supplementary Figure S4b). These results indicate that the traditional anti-cancer drugs commonly used in the clinic do not significantly kill R-CICs in vivo but induce overt liver toxicity and changes in body weight.

\section{Discussion}

It is becoming more evident that only a small subset of cells in the tumor are capable of reproducing the malignant phenotype, named cancer stem cells or CICs, which are also considered to be involved in tumor progression, relapse, and therapeutic resistance. ${ }^{7,20,28}$ Accumulating evidence suggests that proximal colon cancers differ in clinical, pathological, and molecular features from distal cancers. ${ }^{29,30}$ Importantly, recent data suggest that the molecular features of tumors along the bowel subsites (rectum, rectosigmoid, sigmoid colon, descending colon, splenic flexure, transverse colon, hepatic flexure, ascending colon, and cecum) are different. $^{2}$ The gradual changes in CRC molecular features along the bowel may have considerable implications in colon and rectal CICs. Therefore, in the present study we identified rectal cancer cells expressing $\mathrm{CD} 44^{+} \mathrm{CD} 54^{+}$that have the ability to self-renew in vivo and in vitro, form spheres, show rectal differentiation, and recapitulate tumor bulk.

Xenograft tumors generated from CD $44^{+} \mathrm{CD} 54{ }^{+}$rectal cancer cells were highly similar to the primary rectal adenocarcinoma based on morphology and immunostaining patterns, suggesting that CD44 and CD54 are potential R-CIC 


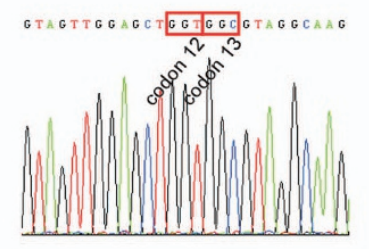

b

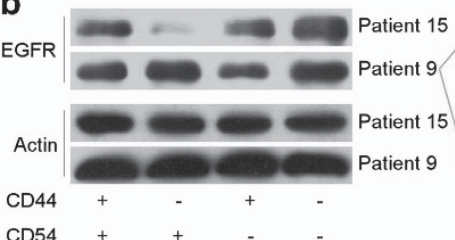

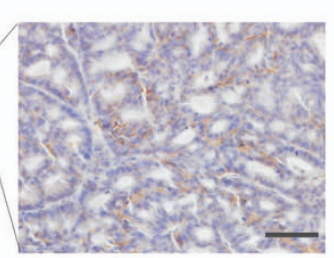

C $\operatorname{CD} 44^{+} \mathrm{CD} 54^{+}$
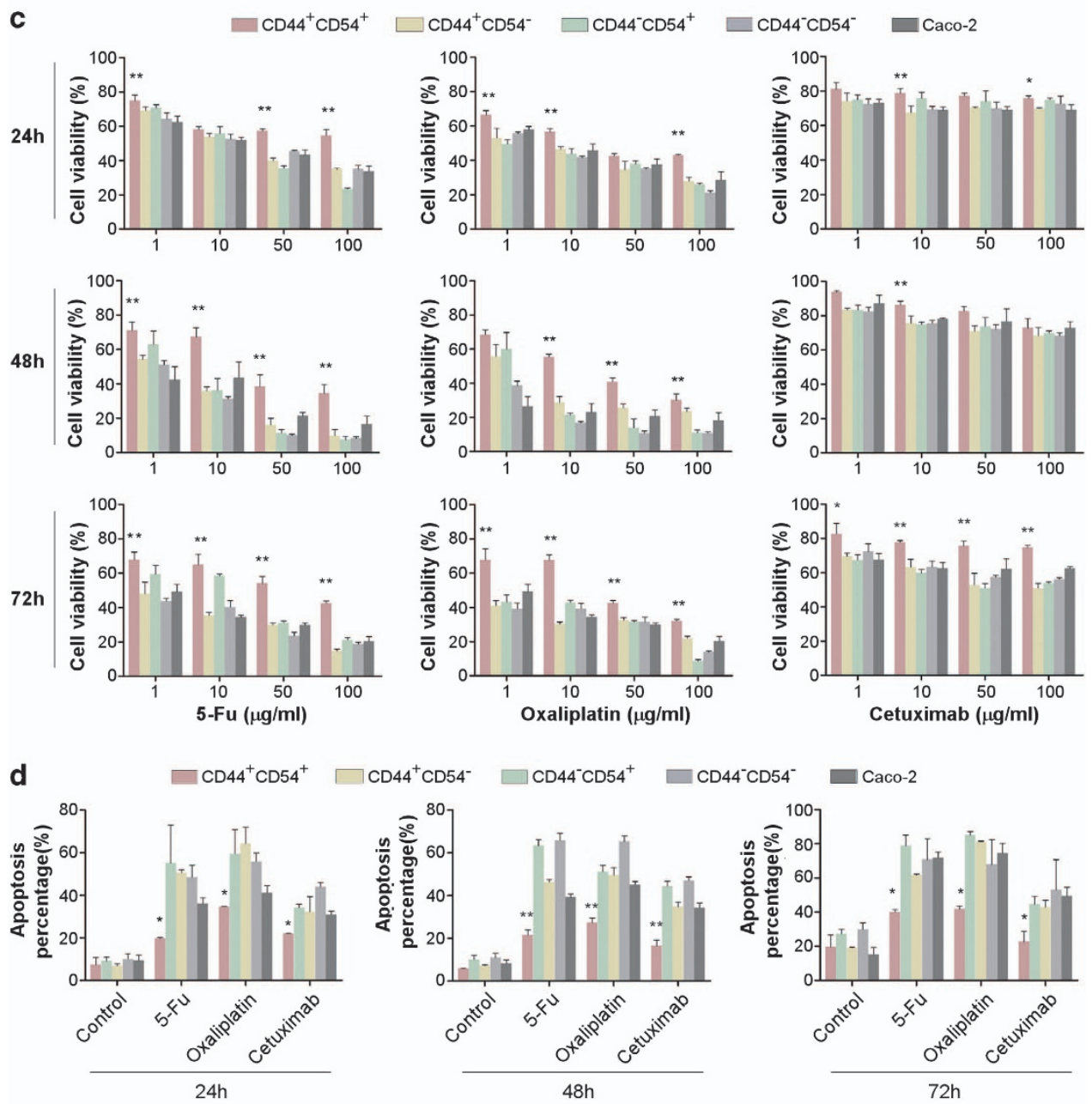

Figure $5 \mathrm{CD} 44^{+} \mathrm{CD} 54^{+} \mathrm{R}$-CICs are resistant to chemotherapeutic agents and apoptosis in vitro. (a) Examination of $k$-ras gene mutation with sequencing, where codons 12 and 13 of exon 2 are wild type. One representative graph of three different tumors is shown. (b) Immunoblotting or immunohistochemical validation of EGFR expression in different cell populations derived from two independent experiments (patients 9 and 15). (c) Percentage of cell viability of different cellular subpopulations and caco-2 cells after treatment with 5-Fu, oxaliplatin, and cetuximab of different concentrations for 24,48 , and $72 \mathrm{~h}$ in vitro. Data are mean \pm S.D. of three independent experiments, each performed with cells from different donors $\left({ }^{* \star} P<0.01,{ }^{*} P<0.05\right.$; patients 9,11 , and 15$)$. (d) Cell apoptosis percentage of different cellular subpopulations and caco-2 cells after treatment with 5-Fu, oxaliplatin, or cetuximab for 24,48 , or $72 \mathrm{~h}$. Data are mean \pm S.D. of three independent experiments, each performed with cells from different donors $\left({ }^{\star *} P<0.01,{ }^{*} P<0.05\right.$; patients 9,11 , and 15$)$

markers and, therefore, that the population of $\mathrm{CD} 44^{+} \mathrm{CD} 54^{+}$ rectal cancer cells contain $\mathrm{CICs}$. The results also showed that the $\mathrm{CD} 44^{+} \mathrm{CD} 54^{+}$population represents a small fraction of cells in the rectospheres, as the majority of sphere cells did not display $\mathrm{CIC}$ properties. ${ }^{24}$ After induction, these spherical cells differentiated to rectal cancer cells expressing CK20 compared with rectospheres expressing Bmi1 and Lgr5, indicating that these spherical cells were undifferentiated. As the $\mathrm{CD} 44^{+} \mathrm{CD} 54^{+}$cancer cellular population likely contains $\mathrm{CICs}$, the remainder of the CD44 ${ }^{+} \mathrm{CD} 54^{+}$subset of cells in the spheroids may represent progeny derived from the $\mathrm{ClCs}$ in the spheres. In addition, we also found that all cellular subpopulations derived from spherical cells not only express epithelial features but also carry properties found in mesenchymal cells. Furthermore, the R-CICs, which have been involved in potential EMT behavior, were found in several solid CICs, including colon CICs. ${ }^{24,31}$ Importantly, this subtype was found to be associated with poor prognosis of CRC patients. ${ }^{32}$ As the R-CICs and their progenies possess mesenchymal phenotypes, cancer cells would have the ability to break through the structural constraints imposed by tissue architecture. $^{33,34}$ Thus the R-ClCs with mesenchymal 
a
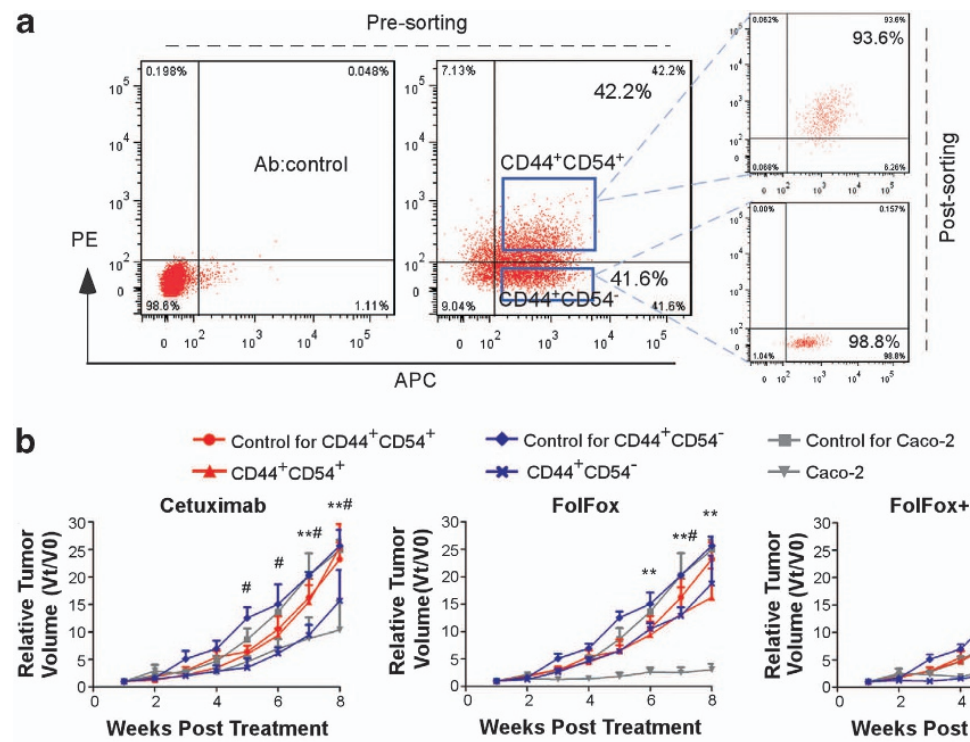

$$
\begin{aligned}
& \rightarrow \text { Control for Caco-2 } \\
& \rightarrow \text { Caco-2 }
\end{aligned}
$$

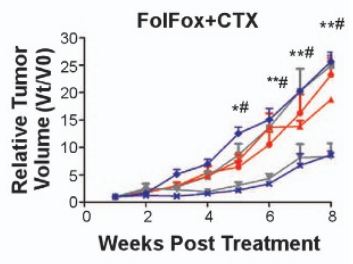

C

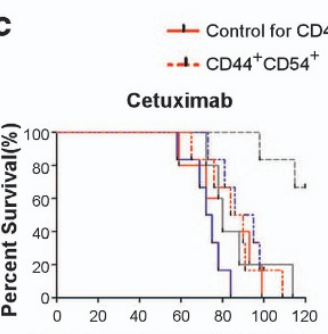

Days from Tumor Cell Injection
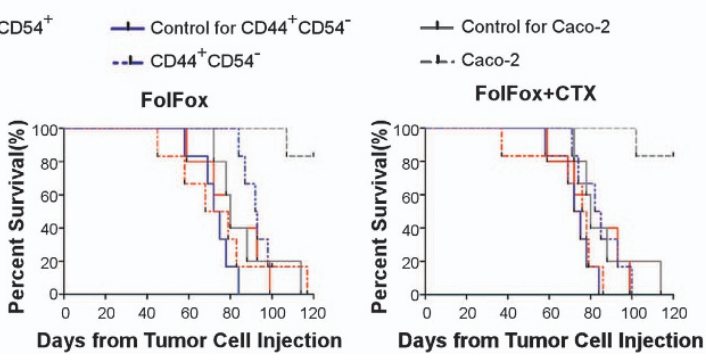

Figure $6 \mathrm{CD}_{4}{ }^{+} \mathrm{CD} 54^{+} \mathrm{R}$-CICs resist FolFox and cetuximab therapy in vivo. (a) The definition of CD44 ${ }^{+} \mathrm{CD} 54^{+}$and $\mathrm{CD} 44^{+} \mathrm{CD} 54^{-}$cellular populations in rectospheroids and the resultant purity after cell sorting. (b) Treatment of tumor-bearing mice generated from $\mathrm{CD} 44^{+} \mathrm{CD} 54^{+} \mathrm{R}-\mathrm{ClCs}, \mathrm{CD} 44^{+} \mathrm{CD} 54^{-}$, and caco-2 cells with cetuximab, FolFox, and cetuximab plus FolFox in vivo. Data are mean tumor size \pm S.D. of five tumors per group derived from two independent experiments from different patients. ( ${ }^{\#} P<0.01, \mathrm{CD} 44^{+} \mathrm{CD} 54{ }^{-}$compared with its control; ${ }^{* *} P<0.01,{ }^{*} P<0.05$; Caco2 cells compared with its control). (c) Survival of tumor-bearing mice derived from $\mathrm{CD}_{4}{ }^{+} \mathrm{CD} 54^{+} \mathrm{R}$-CICs $\left(P=0.684\right.$, cetuximab; $P=0.824$, FolFox; $P=0.207$, FolFox-cetuximab), CD44 ${ }^{+} \mathrm{CD} 54^{-}(P=0.019$, cetuximab; $P=0.001$, FolFox; $P=0.067$, FolFox-cetuximab), and caco-2 cells $(P=0.003$, cetuximab; $P=0.003$, FolFox; $P=0.003$, FolFox-cetuximab) treated with different regimens

features provide a potential resource for rectal cancer recurrence and metastasis.

To the best of our knowledge, there have been no reports describing the exclusive expression of CD44 and CD54 in CICs of CRC aside from a publication by Cui et al. ${ }^{35}$ Interestingly, numerous $\mathrm{CIC}$ markers that have been identified seem to have important roles on immunocytes, such as CD44, ${ }^{17}$ CD13, ${ }^{36}$ CD47, ${ }^{37}$ and CD24. ${ }^{38}$ CD44 is a single transmembrane glycoprotein with cell-cell and cell-matrix interactions, and expression is regulated by the Wnt signaling pathway, which is thought to be crucial for maintaining intestinal stem cells. ${ }^{39}$ CD44 is one of the most frequently described markers of CICs in numerous other malignancies and has been described as part of the signature of $\mathrm{CICs}$ from colon carcinomas. $^{22}$ CD54 (also called intercellular adhesion molecule-1) is a member of the immunoglobulin super-family and is widely expressed in tumors, stroma, and immune cells. Here, we show that CD $44{ }^{+}$CD54 ${ }^{+}$cells exhibit CIC capabilities in rectal cancer tissues, which is consistent with previous reports of these markers in gastric cancer stem cells. ${ }^{23}$

CICs are defined functionally by their ability to initiate tumorigenesis. Thus the formation of a tumor from a transplant is a gold standard for CIC identification. ${ }^{40}$ Our results confirmed the existence of a population of a self-renewing subset of CD44 ${ }^{+} \mathrm{CD} 54{ }^{+}$cells within human primary rectal adenocarcinoma tissues. These cells, although present at a significantly higher percentage in sphere cells compared with differentiated cells, represent only a small subset of cells able to form colonies in vitro. In serial transplantation assays, the $\mathrm{CD} 44^{+} \mathrm{CD} 54^{+}$cell fraction showed a dramatically higher ability to form tumors than other cell subpopulations. In the double-positive cellular subpopulation, 100 cells could initiate xenograft tumorigenesis after subcutaneous injection. Our findings indicate that CD $44^{+} \mathrm{CD} 54^{+}$ cells possess the characteristics of $\mathrm{CICs}$. Considering that only a fraction of $\mathrm{CD} 44^{+} \mathrm{CD} 54^{+}$rectal cancer cells possess the ability of $\mathrm{CICs}$, more specific markers are required to identify and isolate R-CICs for prediction of the outcome of rectal adenocarcinomas.

Although surgical resection of primary and metastatic disease is an option for some patients, the majority of rectal cancer patients cannot be eradicated by curative surgery and thus radio-chemotherapies serve as the mainstay of treatment. ${ }^{41}$ Chemotherapy resistance of $\mathrm{CICs}$ has been described in a variety of epithelial malignancies, including breast, ${ }^{42}$ head and neck, ${ }^{43}$ and pancreatic cancer. ${ }^{44}$ Our data showed that $\mathrm{CD} 44^{+} \mathrm{CD} 54^{+}$cells are enriched and resistant to apoptosis after treatment with 5-Fu, oxaliplatin, and 
cetuximab, suggesting that $\mathrm{CD} 44{ }^{+} \mathrm{CD} 54{ }^{+} \mathrm{R}-\mathrm{CIC}$ s have the ability to resist conventional chemotherapeutic and targeted agents in vitro. In contrast, the remaining non-CIC populations are easily killed by these drugs. Recent studies have shown similar data derived from colon cancer xenografts. ${ }^{6,7}$ Dylla et $a l^{20}$ demonstrated that this was the only CIC population that remained following treatment with the cytotoxic drugs irinotecan and cyclophosphamide. Our study also showed that $\mathrm{CD} 44^{+} \mathrm{CD} 54{ }^{+}$-initiated tumor-bearing mice not only demonstrated little benefit from conventional chemotherapeutic and targeted therapies but also suffer more side effects, including weight loss and liver toxicity, compared with $\mathrm{CD} 44^{+} \mathrm{CD}^{-} 4^{-}$- and caco-2-initiated tumor-bearing mice. These results indicate that traditional cancer therapies target rapidly dividing tumor cells but not $\mathrm{CICs} .{ }^{45}$ However, whether the effects of the R-CIC and conventional drug interaction induce more severe liver toxicity remains to be determined in subsequent studies. We also found that the shortest overall survival occurred in the combined FolFox-cetuximab treatment group compared with the groups receiving FolFox and cetuximab alone, indicating that a combination of FolFox and cetuximab do not prolong overall survival, even in patients with $k$-ras wild-type tumors. However, this treatment regimen is controversial in the treatment of metastatic CRC. ${ }^{46,47}$ Thus our findings may explain the often-encountered clinical scenario, wherein tumors shrink or even transitorily disappear with chemotherapy followed by subsequent local recurrence or adapted growth at distal locations, which is hypothesized to be tightly linked with the biology of $\mathrm{CICs}^{48}$

In summary, we have shown that cancer-initiating potential exists in the rare $\mathrm{CD} 44^{+} \mathrm{CD} 54^{+}$cellular subpopulation in rectal cancer and that conventional anti-cancer chemotherapeutics and targeted drugs cannot effectively eradicate CD $44{ }^{+} \mathrm{CD}_{4}{ }^{+} \mathrm{R}-\mathrm{ClCs}$. Current models of R-CICs and chemoresistance have implicated intrinsically drug-resistant CICs as the driving force behind tumor recurrence following therapy. Therefore, the molecular characterization of tumorigenic R-CICs is crucial in order to develop new therapeutic strategies.

\footnotetext{
Materials and Methods

Sample collection. Tumor tissues were obtained from patients who underwent colorectal resection for primary colorectal adenocarcinoma at the Department of Gastrointestinal Surgery, West China Hospital, Sichuan University. Informed consent was obtained from all the patients who provided samples and the West China Hospital of Sichuan University Institutional Ethics Committees approved this study.
}

Drugs. In vitro experiments: oxaliplatin, 5-Fu, and calcium folinate were purchased from Sigma Co. (St. Louis, MO, USA). In vivo experiments: cetuximab (Erbitux), oxaliplatin, 5-Flu, and calcium folinate were purchased from the West China Hospital Pharmacy (Sichuan, China).

Cancer tissue disaggregation and primary cell culture of rectal CICs. Cancer tissues collected from primary surgical specimens or mouse xenografts were immediately minced on ice, suspended in DMEM/F12 medium (HyClone, Logan, UT, USA), and dissociated with collagenase (Sigma). Enzymatically disaggregated suspensions were filtered and washed three times with phosphate-buffered saline (PBS). Contaminating blood cells were removed by incubation in ammonium chloride-potassium phosphate hypotonic buffer. The dissociated single tumor cells were placed under stem cell conditions in serum-free DMEM/F12 supplemented with human recombinant EGF (Peprotech,
Rocky Hill, NJ, USA) and bFGF (Peprotech) and cultured on Ultra Low Attachment plates (Corning, Corning, NY, USA).

Flow cytometry and cell sorting. Before flow cytometry analysis, the PEcy7-CD45 and PE-CD31antibodies were added to the samples to deplete hematopoietic and endothelial cells. To minimize experimental variability and loss of cell viability, all experiments were performed on fresh tumor cell suspensions prepared shortly before flow cytometry. Spheres and differentiated cells were dissociated into single cells by Accutase (Invitrogen, Guangzhou, China). Antibody staining was performed in PBS supplemented with $0.1 \%$ bovine serum albumin (BSA). Cells were subsequently stained with antibodies at concentrations recommended by the suppliers. Antibodies used in this study include: anti-human CD10-PE/Cy7, CD13-APC, CD24-FITC, CD29-PE, CD31-PE, CD34-FITC, CD44APC, CD45-PE/cy5, CD54-PE, CD58-PE, CD66-PE, CD71-PE, CD117-PE, CD133-APC, CD184-APC, CD326-PE/Cy5.5 (all the above antibodies were purchased from BD Biosciences, San Jose, CA, USA). After 30 min on ice, stained cells were washed of excess unbound antibodies, resuspended in PBS supplemented with $0.1 \% \mathrm{BSA}$, and dead cells were excluded by staining with 7AAD-PE/Cy5.5. Flow cytometry analysis was performed using a BD FACSAria cell sorter (BD Biosciences).

Immunohistochemistry, immunofluorescence and immunoblotting. Immunostaining analysis of cells and tumor specimens from mice or clinical patients was performed as described by Todaro et al. ${ }^{6}$ Details of immunohistochemistry and immunofluorencent assay are provided in the Supplementary Methods.

Drug-resistant experiments in vitro. The different cell fractions $\left(\mathrm{CD} 44^{+} \mathrm{CD}_{4} 4^{+}, \mathrm{CD}_{4} 4^{+} \mathrm{CD} 54^{-}, \mathrm{CD} 44^{-} \mathrm{CD}_{4}{ }^{+}\right.$, and $\left.\mathrm{CD} 44^{-} \mathrm{CD} 54^{-}\right)$from fluorescence-activated cell sorting (FACS)-sorted spherical cells were inoculated into 96-well plates (10000 cells per well) in triplicate on the day before testing. Each well was supplied with SFM together with the indicated chemotherapy agent at different concentrations, such as $5-\mathrm{Fu}$, oxaliplatin, cetuximab, or solvent as a control. The number of viable cells was evaluated after 24,48 , and $72 \mathrm{~h}$ later, respectively, using the Cell Counting Kit-8 (Dojindo Laboratories, Kumamoto, Japan) following the manufacturer's instructions. After $1-4 \mathrm{~h}$, the percentage of cell growth was calculated by comparing the $450 \mathrm{~nm}$ readings from treated and control wells.

In apoptosis experiments, the sorted cellular subpopulation $\left(\mathrm{CD} 44^{+} \mathrm{CD} 54^{+}\right.$ $\mathrm{CD} 44^{+} \mathrm{CD} 54^{-}, \mathrm{CD} 44^{-} \mathrm{CD} 54^{+}$, and $\mathrm{CD} 44^{-} \mathrm{CD} 54^{-}$) derived from spherical cells were cultured in six-well plates (200 000 cells per well) in triplicate on the day before testing. Each well was supplied with SFM together with the indicated chemotherapeutic agent ( $50 \mu \mathrm{g} / \mathrm{ml} 5-\mathrm{Fu}$, oxaliplatin, or cetuximab) or solvent as a control. The treated cells were digested with free-EDTA trypsin and incubated with Annexin V and Propidium iodide (PI) following the supplier's instructions. Then cells were tested with a FACS Aria (BD Biosciences).

Xenotransplantation experiments. Male or female nude mice (BALB/C strain), 4-6-weeks old, were purchased from the Beijing Experimental Animal Center of the Chinese Academy of Sciences (Beijing, China). Mice in this study were housed under pathogen-free conditions, and all animal studies were carried out according to the animal protocol approved by the Sichuan University Institutional Animal Care and Use Committee.

In all the experiments, a small aliquot of cells was set aside to confirm cell counts and viability using conventional techniques (i.e., trypan blue exclusion) or 7-AAD staining. Once cell counts and viability were confirmed, cells were diluted to appropriate injection doses, mixed with BD Matrigel (BD Biosciences) at a 1:1 ratio, and injected s.c. in nude mice on the ventral wall. Injected mice were euthanized when the established criteria for end-stage disease were reached. End-stage disease was defined as death, loss of grooming behavior, or when tumor reached a maximum diameter of $2 \mathrm{~cm}$.

In drug therapy, male or female nude mice 6-8 weeks of age were injected s.c. with $2 \times 10^{4} \mathrm{CD} 44^{+} \mathrm{CD} 54^{+}$cells, $1 \times 10^{5} \mathrm{CD} 44^{+} \mathrm{CD} 54^{-}$cells, or $2 \times 10^{6}$ caco-2 cells. Tumor-bearing mice were randomly grouped to initiate drug treatment until xenograft tumors reached a size of $0.2 \mathrm{~cm}^{3}$ and then mice were started on their respective treatment regimens (solvent, cetuximab, FolFox, or the combination of cetuximab and FolFox). The cetuximab dose for all experiments was $0.3 \mathrm{mg}$ twice weekly for 4 weeks. The FolFox regimen is composed of 5 -Fu $(15 \mathrm{mg} / \mathrm{kg} /$ day for 5 days a week for 2 weeks), calcium folinate $(20 \mathrm{mg} / \mathrm{kg} /$ day for 5 days a week for 
2 weeks), and oxaliplatin (10 mg/kg once a week for 4 weeks). Equal volumes of sodium chloride $(\mathrm{NaCl})$ or lgG was used as a control. Tumor volume measurements were evaluated by digital calipers and calculated by the formula $(\pi) / 6 \times$ (large diameter) $\times\left(\right.$ small diameter). ${ }^{2}$ There were $4-5$ mice in each treatment group. All drugs were administered by intraperitoneal (i.p.) injection. Mice were weighed and tumors were scaled weekly throughout the duration of the study. Progression of cancer was monitored, and mice were euthanized when the established criteria for end-stage disease were reached.

DNA/RNA extraction and real-time quantitative PCR. Total RNA of cells was extracted with a Trizol reagent kit (Takara Biotechnology Co., Ltd. Dalian, China) according to the manufacturer's protocol. Subsequently, reversetranscription of RNA by PCR was performed using a Takara SYBR real-time PCR kit for target gene. Details of DNA/RNA extraction and PCR are provided in the Supplementary Methods.

Statistical analyses. All the experimental data were expressed as means \pm S.D. and statistically analyzed. Differences in mean values between groups were analyzed by two-way ANOVA with repeated measures followed by Bonferroni's post-tests (in vivo experiments). Differences in mean values between groups were analyzed by one-way ANOVA with repeated measures followed by Tukey's post-tests (in vitro experiments). Survival data were analyzed by Kaplan-Meier and log-rank tests. Differences of $P<0.05$ were considered significantly different. All statistical analyses were performed using the GraphPad Prism5 statistical software (GraphPad Software, Inc., San Diego, CA: USA).

\section{Conflict of Interest}

The authors declare no conflict of interest.

Acknowledgements. The relevant institutional Ethics Committees approved this study. We thank the participants and their families for their kind cooperation, generosity, and patience. We appreciate Lin Chen (The University of Newcastle, Australia) for diligent language checking of the manuscript. This study was supported by the Natural Science Foundation of China (No.30830100 to ZG, No.31171384 to HX and No.81201683 to CT), the project of National Basic Research Program of China (2009CB941200) and the Key Project of Chinese Ministry of Education (to XM No. 109136)

\section{Author Contributions}

FCW and CT: conception and design, collection and assembly of the data, and data interpretation; SYN, GYZ, ZSL, LR, OYSY and ZX: collection and assembly of data; LY, MWT, HJK, LY, SXF and BH: conception and design, data analysis and interpretation, and critical reading of the manuscript; ZZG and MXM: conceptual and design, collection and assembly of data, data analysis and interpretation, and manuscript revising.

1. Jemal A, Siegel R, Xu J, Ward E. Cancer statistics 2010CA Cancer J Clin 2010; 60 277-300.

2. Yamauchi M, Morikawa T, Kuchiba A, Imamura Y, Qian ZR, Nishihara R et al. Assessment of colorectal cancer molecular features along bowel subsites challenges the conception of distinct dichotomy of proximal versus distal colorectum. Gut 2012; 61: 847-854.

3. Yu H, Harris RE, Gao YT, Gao R, Wynder EL. Comparative epidemiology of cancers of the colon, rectum, prostate and breast in Shanghai, China versus the United States. Int J Epidemiol 1991; 20: 76-81.

4. Cunningham D, Atkin W, Lenz HJ, Lynch HT, Minsky B, Nordlinger B et al. Colorectal cancer. Lancet 2010; 375: 1030-1047.

5. Ricci-Vitiani L, Fabrizi E, Palio E, De Maria R. Colon cancer stem cells. J Mol Med 2009; 87 : 1097-1104.

6. Todaro M, Alea MP, Di Stefano AB, Cammareri P, Vermeulen L, Lovino F et al. Colon cancer stem cells dictate tumor growth and resist cell death by production of interleukin-4. Cell Stem Cell 2007; 1: 389-402.

7. Pang R, Law WL, Chu AC, Poon JT, Lam CS, Chow AK et al. A subpopulation of CD26 + cancer stem cells with metastatic capacity in human colorectal cancer. Cell Stem Cell 2010, 6: 603-615.

8. Singh SK, Hawkins C, Clarke ID, Squire JA, Bayani J, Hide T et al. Identification of human brain tumour initiating cells. Nature 2004; 432: 396-401.

9. Al-Hajj M, Wicha MS, Benito-Hernandez A, Morrison SJ, Clarke MF. Prospective identification of tumorigenic breast cancer cells. Proc Natl Acad Sci USA 2003; 100 3983-3988.
10. Fang D, Nguyen TK, Leishear K, Finko R, Kulp AN, Hotz S et al. A tumorigenic subpopulation with stem cell properties in melanomas. Cancer Res 2005; 65: 9328-9337.

11. Dembinski JL, Krauss S. Characterization and functional analysis of a slow cycling stem cell-like subpopulation in pancreas adenocarcinoma. Clin Exp Metastas 2009; 26: 611-623.

12. Eramo A, Lotti F, Sette G, Pilozzi E, Biffoni M, Di Virgilio A et al. Identification and expansion of the tumorigenic lung cancer stem cell population. Cell Death Differ 2008; 15 : 504-514

13. Chen T, Yang K, Yu J, Meng W, Yuan D, Bi F et al. Identification and expansion of cancer stem cells in tumor tissues and peripheral blood derived from gastric adenocarcinoma patients. Cell Res 2012; 22: 248-258.

14. O'Brien CA, Pollett A, Gallinger S, Dick JE. A human colon cancer cell capable of initiating tumour growth in immunodeficient mice. Nature 2007; 445: 106-110.

15. Ricci-Vitiani L, Lombardi DG, Pilozzi E, Biffoni M, Todaro M, Peschle C et al. Identification and expansion of human colon-cancer-initiating cells. Nature 2007; 445: 111-115.

16. Haraguchi N, Ohkuma M, Sakashita $H$, Matsuzaki S, Tanaka F, Mimori K et al. CD133( + ) CD44 $(+)$ population efficiently enriches colon cancer initiating cells. Ann Surg Oncol 2008; 15: 2927-2933

17. Du L, Wang HY, He LY, Zhang JY, Ni BY, Wang XH et al. CD44 is of functional importance for colorectal cancer stem cells. Clin Cancer Res 2008; 14: 6751-6760.

18. Fang DD, Kim YJ, Lee CN, Aggarwal S, McKinnon K, Mesmer D et al. Expansion of $\mathrm{CD133}(+)$ colon cancer cultures retaining stem cell properties to enable cancer stem cell target discovery. Brit J Cancer 2010; 102: 1265-1275.

19. Carpentino JE, Hynes MJ, Appelman HD, Zheng T, Steindler DA, Scott EW et al. Aldehyde dehydrogenase-expressing colon stem cells contribute to tumorigenesis in the transition from colitis to cancer. Cancer Res 2009; 69: 8208-8215.

20. Dylla SJ, Beviglia L, Park IK, Chartier C, Raval J, Ngan L et al. Colorectal cancer stem cells are enriched in xenogeneic tumors following chemotherapy. PLoS One 2008; 3: e2428.

21. Shmelkov SV, Butler JM, Hooper AT, Hormigo A, Kushner J, Milde T et al. CD133 expression is not restricted to stem cells, and both CD133(+ ) and CD133(-) metastatic colon cancer cells initiate tumors. J Clin Invest 2008; 118: 2111-2120.

22. Dalerba P, Dylla SJ, Park IK, Liu R, Wang X, Cho RW et al. Phenotypic characterization of human colorectal cancer stem cells. Proc Natl Acad Sci USA 2007; 104: 10158-10163.

23. Chen T, Yang K, Yu J, Meng W, Yuan D, Bi F et al. Identification and expansion of cancer stem cells in tumor tissues and peripheral blood derived from gastric adenocarcinoma patients. Cell Res 2011; 22: 248-258.

24. Hwang WL, Yang MH, Tsai ML, Lan HY, Su SH, Chang SC et al. SNAIL regulates interleukin-8 expression, stem cell-like activity, and tumorigenicity of human colorectal carcinoma cells. Gastroenterology 2011; 141: 279-291; 291 e271-275

25. Mani SA, Guo W, Liao MJ, Eaton EN, Ayyanan A, Zhou AY et al. The epithelialmesenchymal transition generates cells with properties of stem cells. Cell 2008; 133: 704-715

26. Singh A, Settleman J. EMT, cancer stem cells and drug resistance: an emerging axis of evil in the war on cancer. Oncogene 2010; 29: 4741-4751.

27. Jhawer M, Goel S, Wilson AJ, Montagna C, Ling YH, Byun DS et al. PIK3CA mutation/ PTEN expression status predicts response of colon cancer cells to the epidermal growth factor receptor inhibitor cetuximab. Cancer Res 2008; 68: 1953-1961.

28. Todaro M, Alea MP, Scopelliti A, Medema JP, Stassi G. IL-4-mediated drug resistance in colon cancer stem cells. Cell Cycle 2008; 7 : 309-313.

29. Minoo P, Zlobec I, Peterson M, Terracciano L, Lugli A. Characterization of rectal, proximal and distal colon cancers based on clinicopathological, molecular and protein profiles. Int J Oncol 2010; 37: 707-718

30. van Engeland M, Derks S, Smits KM, Meijer GA, Herman JG. Colorectal cancer epigenetics: complex simplicity. J Clin Oncol 2011; 29: 1382-1391.

31. Sadanandam A, Lyssiotis CA, Homicsko K, Collisson EA, Gibb WJ, Wullschleger S et al. A colorectal cancer classification system that associates cellular phenotype and responses to therapy. Nat Med 2013; 19: 619-625.

32. De Sousa EMF, Wang X, Jansen M, Fessler E, Trinh A. Poor-prognosis colon cancer is defined by a molecularly distinct subtype and develops from serrated precursor lesions. Nat Med 2013; 19: 614-618.

33. Brabletz T, Jung A, Spaderna S, Hlubek F, Kirchner T. Opinion: migrating cancer stem cells-an integrated concept of malignant tumour progression. Nat Rev Cancer 2005; 5 : 744-749.

34. Brabletz T, Jung A, Reu S, Porzner M, Hlubek F, Kunz-Schughart LA et al. Variable beta-catenin expression in colorectal cancers indicates tumor progression driven by the tumor environment. Proc Natl Acad Sci USA 2001; 98: 10356-10361.

35. Cui L, Ohuchida K, Mizumoto K, Moriyama T, Onimaru M, Nakata K et al. Prospectively isolated cancer-associated $\mathrm{CD} 10(+)$ fibroblasts have stronger interactions with CD133(+) colon cancer cells than with CD133(-) cancer cells. PLoS One 2010; 5: e12121

36. Christ B, Stock P, Dollinger MM. CD13: waving the flag for a novel cancer stem cell target. Hepatology 2011; 53: 1388-1390.

37. Harrington M. Blocking CD47 to stop tumor growth. Lab Anim 2012; 41: 111.

38. Yeung TM, Gandhi SC, Wilding JL, Muschel R, Bodmer WF. Cancer stem cells from colorectal cancer-derived cell lines. Proc Natl Acad Sci USA 2010; 107: 3722-3727.

39. Kanwar SS, Yu Y, Nautiyal J, Patel BB, Majumdar AP. The Wnt/beta-catenin pathway regulates growth and maintenance of colonospheres. Mol Cancer 2010; 9: 212. 
40. Clarke MF, Dick JE, Dirks PB, Eaves CJ, Jamieson CH, Jones DL et al. Cancer stem cells-perspectives on current status and future directions: AACR Workshop on cancer stem cells. Cancer Res 2006; 66: 9339-9344.

41. Crea F, Danesi R, Farrar WL. Cancer stem cell epigenetics and chemoresistance. Epigenomics-UK 2009; 1: 63-79.

42. Croker AK, Goodale D, Chu J, Postenka C, Hedley BD, Hess DA et al. High aldehyde dehydrogenase and expression of cancer stem cell markers selects for breast cancer cells with enhanced malignant and metastatic ability. J Cell Mol Med 2009; 13: 2236-2252.

43. Chen YC, Chen YW, Hsu HS, Tseng LM, Huang PI, Lu KH et al. Aldehyde dehydrogenase 1 is a putative marker for cancer stem cells in head and neck squamous cancer. Biochem Biophys Res Commun 2009; 385: 307-313.

44. Bednar F, Simeone DM. Pancreatic cancer stem cells and relevance to cancer treatments. J Cell Biochem 2009; 107: 40-45.

45. Fabrizi E, di Martino S, Pelacchi F, Ricci-Vitiani L. Therapeutic implications of colon cancer stem cells. World J Gastroenterol 2010; 16: 3871-3877.
46. Bokemeyer C, Bondarenko I, Makhson A, Hartmann JT, Aparicio J, de Braud F et al. Fluorouracil, leucovorin, and oxaliplatin with and without cetuximab in the first-line treatment of metastatic colorectal cancer. J Clin Oncol 2009; 27: 663-671.

47. Tveit KM, Guren T, Glimelius B, Pfeiffer P, Sorbye H, Pyrhonen $S$ et al. Phase III trial of cetuximab with continuous or intermittent fluorouracil, leucovorin, and oxaliplatin (Nordic FLOX) versus FLOX alone in first-line treatment of metastatic colorectal cancer: the NORDIC-VII study. J Clin Oncol 2012; 30: 1755-1762.

48. Brabletz S, Schmalhofer O, Brabletz T. Gastrointestinal stem cells in development and cancer. J Pathol 2009; 217: 307-317.

(c) (i) (a) Cell Death and Disease is an open-access journal published by Nature Publishing Group. This work is licensed under a Creative Commons Attribution-NonCommercialShareAlike 3.0 Unported License. To view a copy of this license, visit http://creativecommons.org/licenses/by-nc-sa/3.0/

Supplementary Information accompanies this paper on Cell Death and Disease website (http://www.nature.com/cddis) 